\title{
Designing and Assessing Learning
}

\author{
Hong Quan, Dandan Liu, Xiangqin Cun \& Yingchun Lu \\ College of Foreign Languages, Yunnan Agricaltural University \\ Kunming 650201, Yunnan, China \\ Tel: 86-871-522-7828 E-mail: tina04872001@yahoo.com.cn
}

The research is supported by Yunnan Education Science "Eleven Five” Layout project (GY080024).

\begin{abstract}
This paper analyses the design, implementation and assessment of a level 2 module for non-English major students in higher vocational and professional education. 1132001 is a code of module that uses active methods to teach college English in China. It specifically reflects on the module's advantage and defect for developing and improving learning and teaching. The paper concludes with an evaluation and effective suggestions for the next school year.
\end{abstract}

Keywords: Designing module, Learning outcome, Rational/Objective models, Constructive alignment, Deep learning approach, Effective practice and assessment, Reasonable reflection, Redesigning module

\section{Introduction}

As Lu and Luo (2003) say that "the past years have seen many Chinese college graduates, especially the non-English majors, leave school ill-equipped with high skills in English speaking and writing”, college English teaching should aim at improving the students' English knowledge and language communicative ability in China.

The purpose of this module is enable students grasp certain basic knowledge and skill of English; let students have the certain ability of listening, speaking, reading, writing and translation. So students can use simple English to write and communicate in their daily life and business activities in order to lay the foundation to further improve students' English knowledge and communicative ability in future. The redesign of English curriculum is a content of English education reform. In recent years, Chinese universities and colleges have made a great progress in the redesign of English curriculum. It can broaden students' horizons and fits in with the requirement of those employing the graduates in the future. This module also gave me the opportunity to reflect "in action and on action" (Schön, 1983) in relation to the teaching and learning experience it aims to provide.

\section{Context}

As a tutor in level 2 module, 1132001, a module that uses active learning methods to teach English, I am always seeking for a way to build up this module as effective as possible. The students participated in this module would be minority students in higher vocational and professional education in their first semester. Students' major subjects are manufacturing and marketing management of seeding in Yunnan Agricultural University, the students are expected to be able to use English as a tool in their future life.

\section{Learning outcomes}

\subsection{Analysis}

Learning outcomes will help teachers more exactly to tell students what is expected of them, as Jenkins and Unwin (1996) describe that "Learning outcomes are statements of what is expected that a student will be able to DO as a result of a learning activity." It is important to tell students learning outcomes before lecturing.

\subsection{Designing learning outcome}

A curriculum design from which learners 'should not be able to escape without learning or developing' (Cowan, 1998, quoted in Biggs, 2003) so the prior basic requirement of this module is to cultivation of students' practice ability, while enhancing student's basic knowledge and skill of English. By the end of the course study this term, (1) students should be understand 1000 new words and phrases, and 100 Specialized English words; (2) students can follow and understand dialogues; (3) students can use English to communicate in classroom, daily life and business activities; (4) students can read and understand brief practical article, such as business letter, fax, technical description; (5) students can write a propositional business letter which completes at least 100 words within 30 minutes. (6) students can translate article 
with 200 English words per hour when the number of new words are less than 5\% in the article. The learning outcome should encourage students improve their English level.

\subsection{Implementation}

At the beginning of this term, I told my students their leaning outcomes including six aspects as motioned above. Most of my students are surface learners, so in order to help them develop their ability of listening, speaking, reading, writing and translation, I need to help them change their learning approaches, so they adopt appropriate learning strategies, and I implement as follows:

(1) According to Ramsden (2003) describe that one of University teacher's theories of teaching is making students busy and using a set of efficient actions, I gave the students task-based instruction in session. At the start of each session, I told the students the learning outcome. For example, I focus on new words and phrases this session, and I will focus on listening or speaking next session, etc.

(2) As Biggs (2003, p27) states that "Constructive alignment makes the students do the real work, the teacher simply acts as broker between the student and a learning environment that supports the appropriate learning activities", I try to provide active teaching and learning environments, because I completely agree that "Perceptions of teaching environments influence learning outcomes both directly (perceptions to outcomes) and indirectly (perceptions to approaches to outcomes). Thus, changes in teaching environments may have an impact on students' learning outcomes without necessarily affecting their learning approaches." (Lizzio, Wilson, Simons, 2002) Sometimes I use rich and colorful content, interesting vocabulary, and additional exercises, encouraging happiness of examination skills, trying to make my students get more, think more and achieve more. I design some pair tasks, include opening questions, discussing, question and answer pairs. At the same time, as Sieber (2005) suggest that it is possible to show students how things work rather than telling them with computers, and might even, it is enables students to work out for themselves to provide an environment and culture. Apparently, it is more attractive to start a lecture with computer technology than on chalkboard. So I try to use technology to support students' learning as much as possible, such as use CD, DVD, PowerPoint, etc.

(3) The aim of English teaching is not only at mastery of linguistic forms, but also at building student's communicative ability, namely the ability of linguistic use. It should be improve business English teaching and the cultivation of practical personnel in higher vocational and professional education in China. (Cong, 2005) so I focus on practical writing this semester, because the students' major subjects were manufacturing and marketing management of seeding, practical writing will be very helpful after they graduate.

Take writing business letter for example. Firstly, in order to let students know what I expected to and what is the result of a learning activity, I tell my students their learning outcome, that is the students will be able to: (1) identify any area of concern within the module; (2) can read and understand brief practical article; (3) can write a propositional business letter which completes at least 100 words within 30 minutes; (4) know where to get help if needed and improve writing business letter. Secondly, let the students do pair work. In order to make them take deep approach of learning, they discuss the difference of the layout and the content between business letter and personal letter. Thirdly, let the students read and try to understand some brief practical articles. Fourthly, let the students try to write a business letter, suppose for marketing their seeds. The students are too excited to this activity, for it is related to their future jobs. At last, I think that group work is very useful to the students for sharing their ideas in English learning. A benefit of group work or pair work can encourage students use the chance to put their knowledge of English into practice in a comfortable environment, and then providing help, advice and encouragement and improve their practical writing. So I make the students do group work. They share their letters and find where to get help if needed and improve writing their business letters by themselves.

\section{Assessment}

\subsection{Analyses}

Biggs (2003, p178) states "Assessment, like teaching, is something done to students. As teaching yells information and procedures, so assessment classifies the students on the criterion of how well they have absorbed the data thus transmitted."

Problems with assessment most commonly come from a variance between the aims of the course and the assessment. The University has clearly stated that it expects graduates of this university to have a broad range of skills beyond just recalling content knowledge. However if we only assess them on the recall of a series of isolated facts then we can do no more that expect them to learn those facts, and we have no basis to judge whether or not they had actually learnt more than this. It is essential to ensure that the assessment matches all the goals of the course and it would be unreasonable to expect students to put large amounts of their time into activities which will not assist them in getting a good grade 
Steinkuehler and Derry (2001) suggest that "assessments can provide important evidence about what and how students are learning and whether course goals have been met." And "Today's educational settings place an increasing emphasis on understanding, analytical thinking, and communication skills, which in turn has created a growing need for assessment practices, procedures and measures that get beyond mere memorization of "facts." Assessing the effectiveness of a pedagogical or technological intervention in today's academic setting means..."

\subsection{Designing assessment}

As Biggs (2003) offers that "... assessment should test knowledge of the content of the syllabus." the methods of assessment for this module are based on: (1) the final examination contributes $70 \%$ toward the final grade; (2) midterm examination will contribute $20 \%$ of the final course grade; (3) the regular performance will contribute $10 \%$ of the final course grade.

\subsection{Implementation}

I try to combine the learning outcome with the methods of assessment. The paper of the midterm/term examination include two parts, they are listening comprehension (which contribute $15 \%$ of the paper) and reading comprehension (which contribute $75 \%$ of the paper). The assessments of regular performance include the condition of terminal attendance record, homework record and course performance. At the end of this term, the students assign a final grade based on course performance, assignments and two tests.

\section{Reflection}

\subsection{Analyses}

In Hunter's (1982) description of "transfer," Schön (1987) offers about "reflective practitioner", which also applies to student learning, Brookfield's (1986) work on critical reflection and reflection about learning through journaling as described by Cooper (1991). These examples provide a theoretical framework for a constructive of learning and assessing design.

At the end of this term, I find that my students are more interested in English, they tell me the reasons are mostly as follows:

(1) English learning is not a job but a joy, and it is for their future life;

(2) They have much confidence to listen, read and understand English, because they change their learning approach from surface to deep;

(3) They begin to enjoy communicate in English.

So I think the learning outcome designing of this module is effective. But most of the students feel it is too difficult to write a business letter at least 100 words within 30 minutes, and some students can not follow and understand dialogues.

\subsection{Redesigning module}

According to Print's (1993) methods to curriculum design, such as a continuum, vary from rational/Objective to Cyclical to Cycamic/Interaction, I think that this module may redesign based on rational/Objective models (Tyler, 1949; Taba, 1962).

As Print's (1993, p64) say "These approaches to the curriculum process emphasise the fixed sequence of curriculum elements, beginning with objectives and following a sequential pattern from objectives to content, method and finally evaluation", firstly, I reflect on what the students want and need to learn; secondly, I reflect on what the appropriate content is; thirdly, I reflect on how these teaching and learning experiences be effectively organized; finally, I reflect on if the objectives of the curriculum are in fact being achieved. After reflection, I found that there are two aspect of the curriculum need to resign.

$\operatorname{Biggs}(2003)$ discuss the term "constructive alignment" to put together constructivist ideas which notice learning as a process of knowledge construction. Jackie Lublin (no date) says higher order objectives are more likely to encourage students to take a deep approach to learning in the subject. Assessment tasks should mirror and reward these objectives, not merely reward recall.

According to analyze the drawback of designing learning outcomes, the new assessing method is established, it is designed the system of assessing aim which will change into operable teaching behavior. It can objectively, all-rounded, exactly assess student's learning, so I modified the design of module. I add some content in one term of learning outcome "students can follow and understand dialogues." to "students can follow and understand dialogues when speaking slowly." Then I change the last learning outcome like this: "students can write a propositional business correspondence which completes at least 80 words within 30 minutes." So, the resigning learning outcome are: (1) students should be understand 1000 new words and phrases, and 100 Specialized English words; (2) students can follow and understand dialogues when speaking slowly; (3) students can use English to communicate in classroom, daily life 
and business activities; (4) students can read and understand brief practical article, such as business letter, fax, technical description; (5) students can write a propositional business letter which completes at least 80 words within 30 minutes. (6) students can translate article with 200 English words per hour when the number of new words are less than $5 \%$ in the article.

On the other hand, I find that the students excessively concerned about their examination results, most of them are busy to memorize the answer of exercise before examination. This does not comply with the aim of the course, so I will modify the methods of assessment for this module like this: (1) the final examination contributes $40 \%$ toward the final grade; (2) midterm examination will contribute $30 \%$ of the final course grade; (3) the regular performance will contribute $30 \%$ of the final course grade.

\section{Conclusion}

This paper has critically analyzed the result of assessment for designing module, which namely 1132001 . It also has analyzed how the designing module mirrors the constructive alignment (Biggs, 2003) as for constructing aligned teaching and learning process. This paper has provided me the first opportunity to review the 1132001 module. From this process, I know how to encourage students to take a deep learning approach, and I learn how to develop and redesign module. So I believe that the redesigning module will be better suited to my minority students next school year.

\section{References}

Biggs, J. (2003). Teaching for Quality Learning at University, $2^{\text {nd }}$ ed. Maidenhead; OUP.

Brookfield, Stephen.(1986) Understanding and facilitating adult learning. San Francisco: Jossey-Bass.

Cong. (2005). Business English teaching and the cultivation of practical personnel in higher vocational and professional education, Journal of Guangzhou Maritime College.

Cooper, Joanne. (1991). Telling our own stories: The reading and writing of journals or diaries. In Stories Lives Tell, (eds. Witherell, C. \& Noddings, N.) New York: Teachers College Press.

Cowan, J. (1998). On Becoming for Quality Learning at University: What the Student Does. $2^{\text {nd }}$ edition. Berkshire: Open university Press.

Hunter, Madeline. (1982) Mastery Learning. El Segundo, CA: TIP Publications.

Lizzio, A., Wilson, K. and Simons, R. (2002). University students' perceptions of the learning environment and academic outcomes: implications for theory and practice. Studies in Higher Education 27 (1) p27 to 52.

Lu, Luo. (2003). An Exploration of the Innovation in EFL Education within Higher Education in China in the Context of Workplace Globalization, Journal of Guilin University of Electronic Technology.

Print, M. (1993). Curriculum Development and Design, second edition: Allen and Unwin.

Ramsden, P. (2003). Learning to Teach in Higher Education, 2nd ed. London; Routledge.

Schön, D.A. (1983). The Reflective Practitioner: How Professionals Think in Action. New York: Basic Books.

Schön, D.A (1987). Educating the Reflective Practitioner, San Francisco: Jossey-Bass, 1987.

Steinkuehler. C. A \& Derry. S.J. (2001) Strategies for Assessing Learning Effectiveness, from: http://www.alnresearch.org/HTML/AssessmentTutorial/ (accessed 15th December 2007).

Sieber, V. (2005). Learning to teach with technology. Available on the book Enhancing Teaching in Higher Education, edited by Peter Hartley, Amanda Woods and Martin Pill.

Taba, H. (1962). Cufficulum Development: Theory and Practice, In M. Print (ed) Curriculum, Development and Design, Second Edition: Allen and Unwin.

Tylerm, R. W. (1949). Basic Principles of Curriculum and Instruction, In M. Print (ed) Curriculum, Development and Design, Second Edition: Allen and Unwin.

Jenkins \& Unwin. (1996). Writing learning outcomes for the Core Curriculum: How to write learning outcomes, from: http://ncgia.ucsb.edu/giscc/units/format/outcomes.html (accessed 20th December 2007).

Jackie Lublin (No date) Teaching, some very short introductions Deep and Surface Approaches to Learning: An Introduction, http://www.c-sap.bham.ac.uk/resources/guides/student_learning.htm (accessed 25th December 2007).

-(2003)Statement of mutual responsibilities for student learning outcomes: accreditation. Institutions, and programs, CHEA Institute for Research and Study of Accreditation and Quality Assurance, from: http://www.chea.org/pdf/StmntStudentLearningOutcomes9-03.pdf (accessed 27th December 2007). 